\title{
Headspace gas chromatographic analysis of residual solvents in pharmaceuticals: comparison of two matrix media
}

\author{
Vida Vičkačkaitè, \\ Agnieška Jevtuch, \\ Vilius Poškus, \\ Birutè Bugelytè \\ Department of Analytical \\ and Environmental Chemistry, \\ Vilnius University, \\ 24 Naugarduko Street, \\ 03225 Vilnius, Lithuania
}

\begin{abstract}
Dimethylformamide (DMF) and a deep eutectic solvent choline chloride-ethylene glycol (ChCl-Eg) were investigated as potential matrix media for static headspace gas chromatographic (SHS-GC) determination of residual solvents in pharmaceuticals. Sample equilibration temperature, equilibration time and injection time were optimized. In the case of DMF $140^{\circ} \mathrm{C}$ equilibration temperature was applied. For ChCl-Eg equilibration temperature could not exceed $80^{\circ} \mathrm{C}$ as $\mathrm{ChCl}$-Eg started to degrade at elevated temperatures. The higher equilibration temperature of DMF solutions favoured a transition of the analytes to the headspace and consequently resulted in lower detection limits of the analytes. Thus DMF has been considered a more suitable matrix medium than $\mathrm{ChCl}$-Eg and was applied for the SHS-GC determination of residual solvents in pharmaceuticals.
\end{abstract}

Keywords: pharmaceuticals, residual solvents, static headspace gas chromatography

\section{INTRODUCTION}

Residual solvents in pharmaceuticals are considered as volatile organic chemicals that are used or produced during the manufacture of pharmaceutical ingredients, excipients and drug products. Residual solvents may also contaminate products during packaging, storage and transportation [1]. Because residual solvents have no therapeutic benefits but many of them have toxic or environmentally hazardous properties, it must be ensured that they are either not present in products or are only present below recommended acceptable levels [2].

The International Council for Harmonisation of Technical Requirements for Pharmaceutical and

\footnotetext{
*Corresponding author. Email: vida.vickackaite@chf.vu.lt
}

Human Use (ICH) has issued limits for the levels of residual solvents in pharmaceutical products [3, 4 . Residual solvents are classified in three categories. Class 1 solvents are known human carcinogens or are strongly suspected carcinogens and/or environmental hazards and should be avoided. Class 2 solvents are not genotoxic impurities, but with a level of toxicity that must be limited in drug products to the indicated concentration. Class 3 solvents have the lowest risk and are limited to $5000 \mathrm{ppm}$ [1, 5.

Residual solvent analysis can be performed with a large array of analytical techniques but the most frequently used and selective analytical technique is gas chromatography (GC). However, pharmaceutic samples often contain thermolabile or nonvolatile substances. Those substances can 
contaminate the chromatographic system or their peaks in the chromatogram can interfere with peaks of the analyte. Those problems can be solved by combining gas chromatographic analysis with headspace sampling as in the case of headspace sampling only a volatile portion of the sample is subjected to analysis [1, 6].

Several headspace techniques such as static headspace (SHS) [7-11], dynamic headspace [12] and headspace solid phase microextraction [5, 13. can be employed. Static headspace analysis is probably the most widely used technique for residual solvent analysis in pharmaceuticals as it is inexpensive, easy to perform and automate, can be successfully used routinely in control labs. In the static headspace procedure, a sample is placed into a sealed vial and is heated until a thermodynamic equilibrium between a sample and a gas phase is reached. After, a determined volume of the gas phase is injected into the gas chromatograph for analysis [14].

For quantification, it is necessary to achieve that the distribution of the analyte between the calibration solution and the headspace is the same as between the sample and the headspace. The sample must therefore be dissolved or dispersed in a matrix medium that is the same as the solvent used for calibration solutions. The nature of the matrix medium is of primary importance as has an essential influence on the amount of the analytes in the headspace and thus on the determination sensitivity. For residual solvents determination in pharmaceuticals, water [8], dimethylsulfoxide [9, 15], N,N-dimethylacetamide [16], N,N-dimethylformamide (DMF) [15], benzyl alcohol [17], liquid paraffin [18] and ionic liquids [3, 11] were suggested as matrix media. Recently, for residual solvents determination deep eutectic solvents (DESs) have been proposed [7, 8, 19].

DESs are gaining an increasing interest as they are eco-friendly, biodegradable, inexpensive and easy to prepare [20]. They are composed of a hydrogen bond donor and of a hydrogen bond acceptor. Generally, DESs have a low vapour pressure, a relatively wide liquid range and a much lower melting point than that of any of its individual components [21]. Those features make DESs very attractive as matrix media for application in SHS-GC.

The goal of this study was to compare two solvents as matrix media - conventional DMF and recently proposed deep eutectic solvent choline chloride-ethylene glycol (ChCl-Eg) - and to develop a simple and sensitive static headspace gas chromatographic (SHS-GC) procedure for the determination of residual solvents in pharmaceuticals. Five solvents - methanol, ethanol, dichloromethane (DCM), acetone and acetonitrile (ACN) - often used for the synthesis and purification of drug substances were employed as target analytes.

\section{EXPERIMENTAL}

\section{Reagents and samples}

Methanol (99\%), ethanol (96\%), acetonitrile (99.8\%), choline chloride (98\%) and ethylene glycol (99\%) were purchased from Alfa Aesar (Germany). Dichloromethane (99.8\%) was purchased from Merck (Germany). Acetone (99.9\%) and N,Ndimethylformamide (99.8\%) were purchased from Roth (Germany).

The pharmaceuticals investigated were 'Paracetamolis Sanitas' (Sanitas, PharmaSwiss Czech Republic), 'Paracetamol' (Borisovskiy zavod medicinskikh preparatov, Belarus), 'Omeprazol Sandoz' (Sandoz, Netherlands), 'Omeprazole' (Lekpharm, Belarus), Drotaverine hydrochloride 'No-Spa' (UAB Sanofi-Aventis, Lithuania), 'Drotaverine' (Borisovskiy zavod medicinskikh preparatov, Belarus), 'Valerijonas Forte' (Sopharma ${ }^{\oplus}$ Pharmaceuticals, Bulgaria), 'Valerianae radix' (Belmedpreparaty, RUE, Belarus), Amoxiciline 'Ospamox' (Sandoz, Sloenia) and 'Amoxicillin' (Farmlend, Belarus).

Standard solutions of individual analytes (methanol, ethanol, DCM, acetone and ACN), were prepared in DMF (10 $\mathrm{g} \mathrm{l}^{-1}$ each) and in $\mathrm{ChCl}$ Eg (10 $\mathrm{g} \mathrm{kg}^{-1}$ each). Working mixed solutions of the analytes were prepared from standard solutions of individual analytes in DMF or in ChCl-Eg and diluted with a corresponding solvent to a required concentration.

\section{ChCl-Eg preparation}

ChCl-Eg was prepared by the heating method [8]. In brief, $\mathrm{ChCl}$ was mixed with ethylene glycol in the molar ratio 1:2 and the mixture was heated in a glass vial at $80^{\circ} \mathrm{C}$ temperature in a water bath under stirring until the formation of a homogeneous liquid. 


\section{Sample preparation}

$0.2 \mathrm{~g}$ of a grinded sample was placed into a $20 \mathrm{ml}$ headspace vial and $1 \mathrm{ml}$ of DMF was added. The vial was hermetically capped, irradiated with ultrasonic waves for $10 \mathrm{~min}$ and subjected for headspace gas chromatographic analysis.

\section{Instrumentation and conditions}

Headspace gas chromatographic analysis was performed on a PerkinElmer Clarus 580 series gas chromatograph (PerkinElmer, USA) equipped with a flame ionisation detector (temperature $250^{\circ} \mathrm{C}$, hydrogen flow $40 \mathrm{ml} \mathrm{min}^{-1}$, air flow $400 \mathrm{ml} \mathrm{min}^{-1}$,

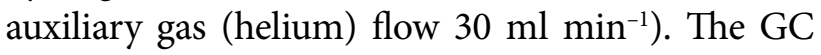
system was equipped with the Elite 200 capillary column $(30 \mathrm{~m} \times 0.25 \mathrm{~mm}$ id, $0.25 \mu \mathrm{m}$ film thickness) (PerkinElmer, USA). Headspace extraction and sample introduction was performed on a PerkinElmer Headspace Sampler Turbomatrix 16 (PerkinElmer, USA) equipped with a balanced pressure system. Twenty millilitre headspace vials were used in all experiments. A headspace vial was positioned in the HS autosampler and equilibrated at selected temperature. The needle temperature and the transition line temperature was by $10^{\circ} \mathrm{C}$ higher than the headspace vial equilibration temperature. The settings of the headspace sampler were $1 \mathrm{~min}$ for pressurization and $0.07 \mathrm{~min}$ for injection. Helium was employed as a carrier gas with 16.7 psi column head pressure. The injector temperature was held at $110^{\circ} \mathrm{C}$. The GC oven temperature was programmed as follows: $40^{\circ} \mathrm{C}$ for $1 \mathrm{~min}$ from 40 to $50^{\circ} \mathrm{C}$ at $10^{\circ} \mathrm{C} \mathrm{min}{ }^{-1}$ and from $50^{\circ} \mathrm{C}$ to $200^{\circ} \mathrm{C}$ at $40^{\circ} \mathrm{C} / \mathrm{min}$.

\section{RESULTS AND DISCUSSION}

\section{Operation conditions}

Five common solvents used in the fabrication of the pharmaceuticals were selected as analytes: methanol, ethanol, dichloromethane, acetone and acetonitrile. The solvents according to the $\mathrm{ICH}$ classification belong to Class 2 and Class 3, their concentration limits are indicated in Table 1. Class 1 solvents were not considered as because of their high toxicity they are avoided and normally are not present in pharmaceuticals.

The nature of the matrix medium is essential for determination sensitivity as it is one of the main parameters that the concentration of the analyte in the headspace depends on. For the determina-
Table 1. Concentration limits of residual solvents in pharmaceuticals

\begin{tabular}{c|cc}
\hline Solvent & Class & Concentration limits, ppm [4] \\
\hline Methanol & 2 & 3000 \\
\hline Ethanol & 3 & 5000 \\
\hline DCM & 2 & 600 \\
\hline Acetone & 3 & 5000 \\
\hline ACN & 2 & 410 \\
\hline
\end{tabular}

tion of residual solvents in pharmaceuticals by the SHS-GC method we tested two solvents as a matrix media - a traditional solvent dimethylformamide and a deep eutectic solvent choline chloride-ethylene glycol.

For the SHS sample heating temperature is one of the main parameters to be optimized. Vapour pressure increases with temperature, thus partition of the analytes between a sample phase and a gas phase will decrease and more of the compound will pass into the headspace. Moreover, the time needed to achieve the equilibrium between a sample and a gas phase at higher temperatures is smaller and the analysis is faster.

Different equilibration temperatures $\left(60-140^{\circ} \mathrm{C}\right)$ were tested for DMF. Higher temperatures were not used as the equilibration temperature should not exceed the boiling point of the matrix medium DMF $\left(152^{\circ} \mathrm{C}\right)$. Under these conditions, the content of the analytes in the headspace permanently increased (Fig. 11). Based on the results, for DMF $140^{\circ} \mathrm{C}$ equilibration temperature was chosen as optimal.

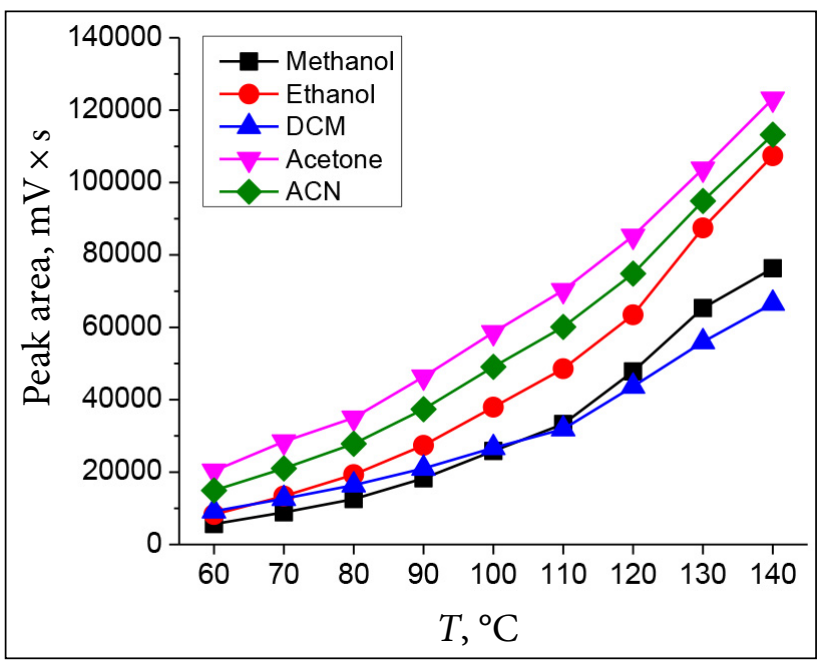

Fig. 1. Influence of SHS equilibration temperature on peak areas of $1 \mathrm{ml} 0.1 \mathrm{~g} \mathrm{l}^{-1}$ analytes solution in DMF (coloured online). Equilibration time $20 \mathrm{~min}$, injection time $0.03 \mathrm{~min}$ 
Deep eutectic solvents are considered especially suitable for SHS, as due to their low vapour pressure their concentration in the headspace is very low and thus analytes are favoured to enter the headspace. Moreover, a high boiling point of DESs allows higher equilibration temperatures.

Unfortunately, the preliminary experiment showed that above $80^{\circ} \mathrm{C} \mathrm{ChCl-Eg} \mathrm{starts} \mathrm{to} \mathrm{decom-}$ pose and peaks of decomposition products appear in the chromatogram close to the peaks of the residual solvents of interest (Fig. 2). Because of that $80^{\circ} \mathrm{C}$ equilibration temperature was considered as optimum for ChCl-Eg.

For the optimisation of equilibration time, $1 \mathrm{ml}$ of $0.1 \mathrm{~g} \mathrm{l}^{-1} \mathrm{DMF}$ solution of the analytes was heat- ed at $140^{\circ} \mathrm{C}$ for $2-20 \mathrm{~min}$. The results presented in Fig. 3a demonstrate that the peak areas levelled at $8 \mathrm{~min}$. This time was considered as optimum and selected for further work.

For the analytes solution in ChCl-Eg ( $1 \mathrm{~g}$ of $\left.0.1 \mathrm{~g} \mathrm{~kg}^{-1}\right)$ the sample was heated at $80^{\circ} \mathrm{C}$ up to 60 min.

Longer equilibration time in comparison with DMF solutions was examined because of the lower equilibration temperature applied and because of the bigger viscosity of the matrix medium. For comparison, at $20^{\circ} \mathrm{C}$ viscosity of DMF is $0.92 \mathrm{mPa} \mathrm{s}$ and that of $\mathrm{ChCl}-\mathrm{Eg}$ is $48.95 \mathrm{mP}$ s [22]. The results demonstrated (Fig. $3 \mathrm{~b}$ ) that the equilibration time was $40 \mathrm{~min}$.

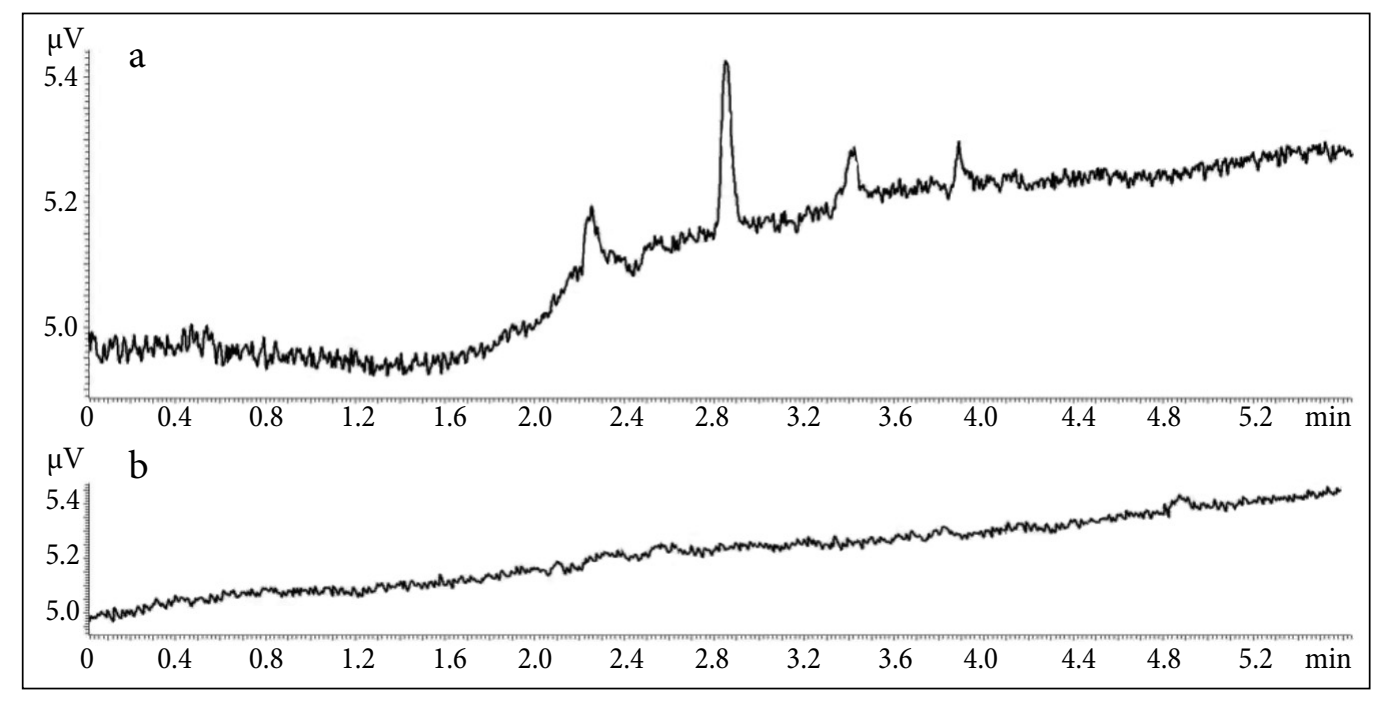

Fig. 2. Headspace chromatograms of $\mathrm{ChCl}-\mathrm{Eg}$ equilibrated at $100^{\circ} \mathrm{C}(\mathrm{a})$ and at $80^{\circ} \mathrm{C}(\mathrm{b})$. Equilibration time $10 \mathrm{~min}$, injection time $0.03 \mathrm{~min}$. For SHS-GC conditions see Experimental

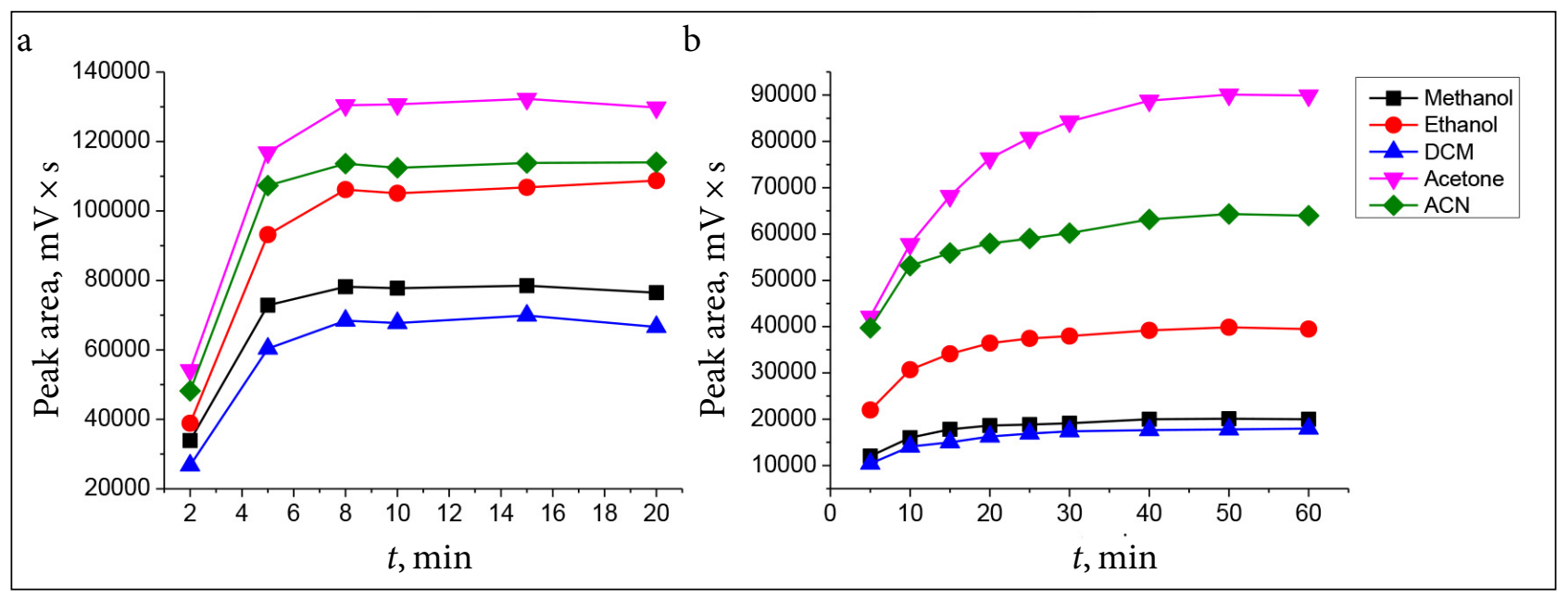

Fig. 3. Influence of SHS equilibration time on peak areas of: (a) $1 \mathrm{ml} 0.1 \mathrm{~g} \mathrm{I}^{-1}$ analytes solution in DMF. Equilibration temperature $140^{\circ} \mathrm{C}$, injection time $0.03 \mathrm{~min}$; (b) $1 \mathrm{~g} 0.1 \mathrm{~g} \mathrm{~kg}^{-1}$ analytes solution in ChCl-Eg (coloured online). Equilibration temperature $80^{\circ} \mathrm{C}$, injection time $0.03 \mathrm{~min}$ 
The volume of the gas phase injected to GC has also been optimized. The more gas phase injected, the bigger peak should be observed. On the other hand, with the increase of injected gas phase volume, peaks can start to broaden and tail. The equipment used was supplied by pressure balanced sampling that allows a direct control of the time width of the vapour plug entering the GC column. Injection times from 0.01 to 0.12 min have been examined. The results presented in Fig. 4 a demonstrate that for DMF solutions peak areas proportionally increased up to 0.09 min injection time with the peak area correlation coefficients bigger than 0.99 . For ChCl-Eg solutions peak areas proportionally increased up to 0.12 min injection time with the peak area correlation coefficients bigger than 0.98 (Fig. $4 \mathrm{~b}$ ). However, as it is demonstrated for acetone and acetonitrile, peak efficiencies decreased with the increase of the injection volume (Fig. 5). Thus the optimum injection time should be selected with respect to the sample. In the case of a good separation of the residual solvent peak, long injection time can be applied. Contrarily, for better separation efficiency shorter injection time should be advantageous. For further work, 0.09 min injection time was considered to be optimal.

\section{Quality parameters}

Quality parameters for both analysed matrix media were determined under the optimized conditions. The calibration curves were drawn with 10 calibration points with three-replicate injections and for all the analytes were linear up to $1 \mathrm{gl}^{-1} \mathrm{inDMF}$ and up to $1 \mathrm{~g} \mathrm{~kg}^{-1}$ in ChCl-Eg. Correlation coefficients, relative

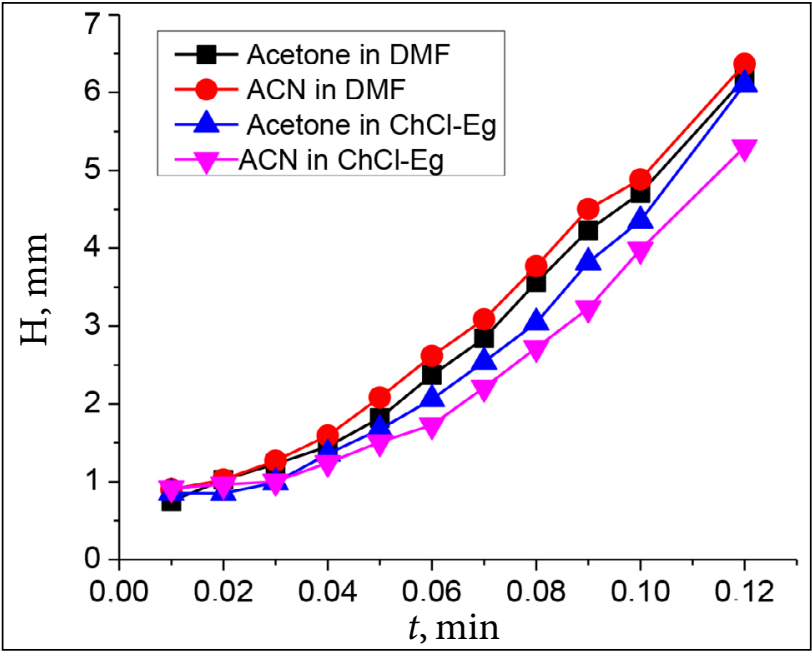

Fig. 5. Theoretical plate height $(\mathrm{H})$ dependence on the injection time at optimal equilibration temperatures and times (coloured online). Analytes concentration in DMF $0.1 \mathrm{~g} \mathrm{I}^{-1}$, analytes concentration in ChCl-Eg $0.1 \mathrm{~g} \mathrm{~kg}^{-1}$

standard deviations (RSDs) and limits of detection (LOD) calculated as three times the baseline noise are presented in Table 2. The relative standard deviations were determined by five-replication analysis at two different concentrations of the analytes and did not exceed $6 \%$.

Detection limits for all the analytes were up to 4 times lower when DMF was used as a matrix medium. This fact could be explained by higher equilibration temperature applied when DMF was used as a diluent. Another advantage of DMF over $\mathrm{ChCl}-\mathrm{Eg}$ is shorter equilibration time (8 $\mathrm{min}$ over $40 \mathrm{~min}$ ). Additionally, $\mathrm{ChCl}$-Eg solutions are more difficult to handle because of their higher viscosity. Based on that, DMF was chosen as a matrix medium for

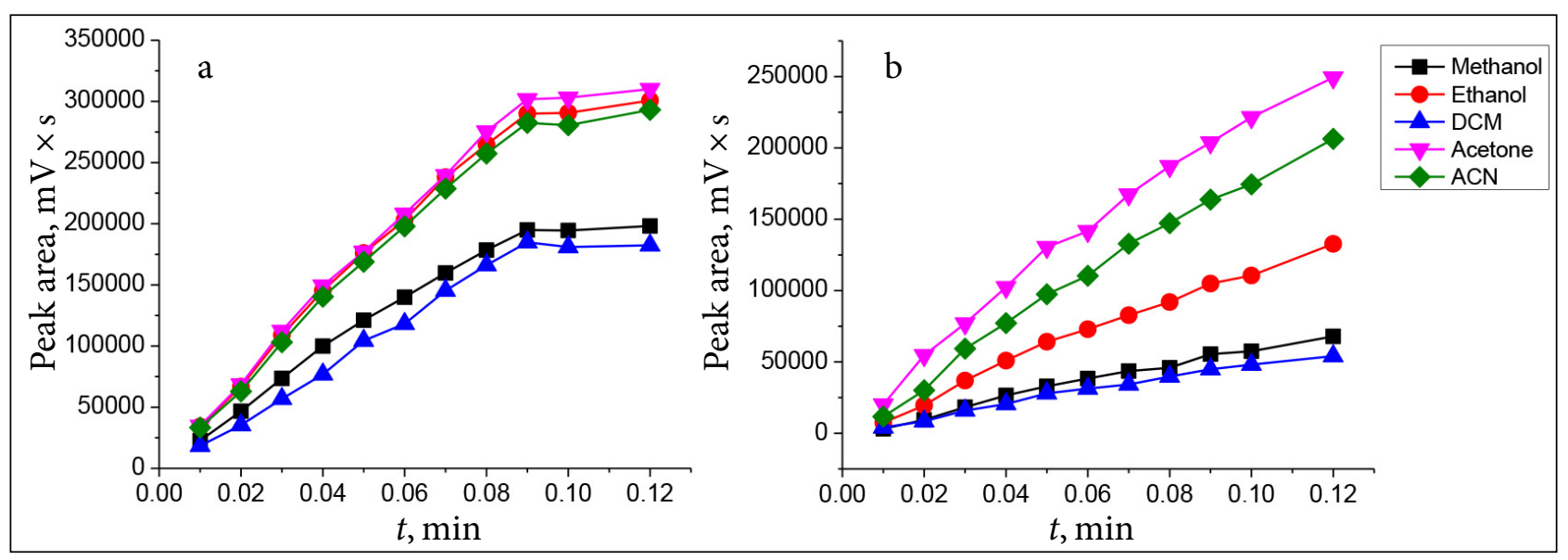

Fig. 4. Influence of SHS injection time on peak areas of: (a) $1 \mathrm{ml} 0.1 \mathrm{~g} \mathrm{l}^{-1}$ analytes solution in DMF. Equilibration temperature $140^{\circ} \mathrm{C}$, equilibration time $8 \mathrm{~min}$; (b) $1 \mathrm{~g} 0.1 \mathrm{~g} \mathrm{~kg}^{-1}$ analytes solution in ChCl-Eg (coloured online). Equilibration temperature $80^{\circ} \mathrm{C}$, equilibration time $40 \mathrm{~min}$ 
Table 2. Analytical figures of merit

\begin{tabular}{|c|c|c|c|c|c|c|c|c|}
\hline \multirow{3}{*}{ Analyte } & \multicolumn{4}{|c|}{ In DMF } & \multicolumn{4}{|c|}{ In ChCl-Eg } \\
\hline & \multirow{2}{*}{$\mathbf{R}^{2}$} & \multirow{2}{*}{ LOD, $\mu \mathrm{g} \mathrm{I}^{-1}$} & \multicolumn{2}{|c|}{ RSD, $\%(n=5)$} & \multirow{2}{*}{$\mathbf{R}^{2}$} & \multirow{2}{*}{ LOD, $\mu \mathrm{g} \mathrm{I}^{-1}$} & \multicolumn{2}{|c|}{ RSD, $\%(n=5)$} \\
\hline & & & $10 \mathrm{mg} \mathrm{l}^{-1}$ & $100 \mathrm{mgl}^{-1}$ & & & $10 \mathrm{mg} \mathrm{kg}^{-1}$ & $100 \mathrm{mg} \mathrm{kg}^{-1}$ \\
\hline Methanol & 0.9997 & 17 & 4.8 & 4.6 & 0.9995 & 68 & 5.9 & 1.0 \\
\hline Ethanol & 0.9995 & 9 & 4.2 & 4.1 & 0.9992 & 25 & 4.8 & 1.5 \\
\hline DCM & 0.9997 & 22 & 5.4 & 4.0 & 0.9931 & 72 & 5.9 & 1.2 \\
\hline Acetone & 0.9999 & 7 & 5.4 & 2.2 & 0.9985 & 18 & 5.1 & 1.7 \\
\hline $\mathrm{ACN}$ & 0.9996 & 12 & 5.0 & 4.2 & 0.9983 & 37 & 6.0 & 2.2 \\
\hline
\end{tabular}

residual solvents determination in real pharmaceutical samples.

\section{Real sample analysis}

In order to evaluate if the matrix of the sample had an influence on the determination of the analytes, two pharmaceuticals - Ospamox and Omeprazole (Bl) - were analysed using the calibration curve method and the multiple standard addition method.

$0.2 \mathrm{~g}$ of a grinded sample was placed into a $20 \mathrm{ml}$ headspace vial and $1 \mathrm{ml}$ of DMF was added. The vial was hermetically capped, irradiated with ultrasonic waves for $10 \mathrm{~min}$ and subjected for headspace gas chromatographic analysis.

In the multiple standard addition method, three different volumes of additions of $1 \mathrm{~g} \mathrm{l}^{-1}$ solution of the analytes were spiked to three portions of the grinded sample ( 0.2 each) and the analysis was carried out as described above.

The results obtained by the calibration curve method and the multiple standard addition method differed less than by $10 \%$. Thus, as the multiple standard addition method requires extra time for making the additions and measurements, the calibration curve method was applied to quantify the analytes in other pharmaceuticals. The results presented in Table 3 demonstrate that one of the tested drugs, Valerianae radix, exceeded the permissible (5000 ppm) ethanol concentration. In other pharmaceuticals the concentrations of all analytes did not exceed the permissible levels. On the other hand, residual solvent concentrations in pharmaceutical products with the same active substance but from different manufacturers may vary significantly. This is illustrated by the chromatograms of Valerianae radix and Valerijonas Forte presented in Fig. 6. Valerijonas Forte is almost free of solvent impurities and

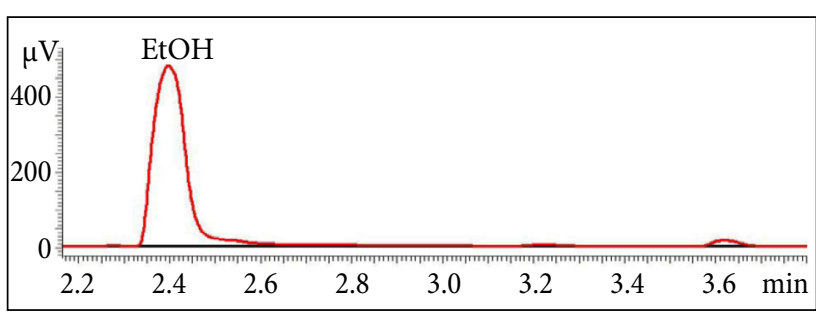

Fig. 6. Valerijonas Forte (black) and Valerianae radix (red) headspace gas chromatograms (coloured online). For SHS-GC conditions see EXperimental

Table 3. Concentration of the analytes in pharmaceuticals, ppm

\begin{tabular}{|c|c|c|c|c|c|}
\hline Pharmaceutical & Methanol & Ethanol & DCM & Acetone & ACN \\
\hline Ospamox & 155 & - & 227 & 16 & 23 \\
\hline Amoxicillin & 85 & 19 & - & 60 & 109 \\
\hline Omeprazol Sandoz & 90 & 37 & 250 & 30 & - \\
\hline Omeprazole & 94 & 67 & - & - & - \\
\hline Omeprazole-Akrikhin & 139 & 72 & 401 & - & - \\
\hline Paracetamolis Sanitas & - & - & 58 & - & 37 \\
\hline Paracetamol & - & 151 & 42 & - & 40 \\
\hline No-Spa & - & 492 & - & - & - \\
\hline Drotaverine & - & 469 & - & - & - \\
\hline Valerijonas Forte & - & 18 & - & - & - \\
\hline Valerianae radix & - & 8607 & - & - & 84 \\
\hline
\end{tabular}


the chromatogram of Valerianae radix shows a high peak in ethanol.

\section{CONCLUSIONS}

Two potential matrix media - a traditional solvent DMF and a deep eutectic solvent ChCl-Eg - for SHS-GC determination of residual solvents in pharmaceuticals have been investigated. It was expected that due to the high boiling point of the DES, high equilibration temperature could be applied. However, ChCl-Eg tends to degrade at elevated temperatures and $80^{\circ} \mathrm{C}$ was the maximal temperature that did not result in the degradation of ChCl-Eg, meanwhile for DMF solutions $140^{\circ} \mathrm{C}$ equilibration temperature could be applied. The higher equilibration temperature of DMF solutions favoured a transition of the analytes to the headspace and consequently resulted in lower detection limits. Thus DMF has been considered a more suitable matrix medium than ChCl-Eg and was applied for residual solvents determination in 11 pharmaceuticals. It was determined that in all the pharmaceuticals investigated except one, residual solvents concentrations did not exceed allowable concentration limits. Only Valerianae radix was found to exceed the permissible ethanol concentration.

To further increase determination sensitivity, thermostable DESs could be promising. Investigations are ongoing.

Received 3 September 2020 Accepted 15 September 2020

\section{References}

1. C. B'Hymer, Pharm. Res., 20, 337 (2003).

2. A. M. Dwivedi, Pharm. Technol. Eur., 14(12) (2002).

3. O. Nacham, T. D. Ho, J. L. Anderson, G. K. Webster, J. Pharm. Biomed. Anal., 145, 879 (2017).

4. ICH Harmonized Guideline. Impurities: Guideline for Residual Solvents Q3C(R6), International Council for Harmonisation of Technical Requirements for Pharmaceuticals for Human Use (2016).

5. M. Mirmoghaddam, M. Kaykhaii, H. Yahyavi, Anal. Methods, 7, 8511 (2015).

6. C. Camarasu, C. Madichie, R. Williams, Trends Analyt. Chem., 25, 768 (2006).

7. W. Zhang, S. Fang, X. Liang, Chromatographia, 82, 1523 (2019).

8. M. Wang, S. Fang, X. Liang, J. Pharm. Biomed. Anal., 158, 262 (2018).
9. J. Tian, A. Rustum, J. Pharm. Biomed. Anal., 128, 408 (2016).

10. X. Z. Feng, G. C. Han, J. Qin, S. Yin, Z. Chen, J. Chromatogr. Sci., 54, 487 (2016).

11. F. H. Liu, Y. Jiang, J. Chromatogr. A, 1167, 116 (2007).

12. M. A. Farajzadeh, H. Dehghani, A. Yadeghari, L. Khoshmaram, Biomed. Chromatogr., 31, e3788 (2017).

13. S. O. Akapo, C. M. McCrea, J. Pharm. Biomed. Anal., 47, 526 (2008).

14. B. Kolb, L. S. Ettre, Static Headspace-Gas Chromatography: Theory and Practice, 2nd edn., Wiley, New Jersey (2006).

15. J. L. Belsky, A. J. Ashley, P. A. Bhatt, et al., AAPS PharmSciTech, 11, doi: 10.1208/s12249-010-9460-6 (2010).

16. S. Pandey, P. Pandey, R. Kumar, N. P. Singh, Braz. J. Pharm. Sci., 47, 379 (2011).

17. K. Urakami, A. Higashi, K. Umemoto, M. Godo, J. Chromatogr. A, 1057, 203 (2004).

18. W. D'Autry, C. Zheng, J. Bugalama, et al., J. Pharm. Biomed. Anal., 55, 1017 (2011).

19. R. Otero, G. Carrera, J. F. Dulsat, J. L. Fabregas, J. Claramunt, J. Chromatogr. A, 1057, 193 (2004).

20. X. Li, K. H. Row, J. Sep. Sci., 39, 3505 (2016).

21. S. C. Cunha, J. O. Fernandes, Trends Analyt. Chem., 105, 225 (2018).

22. D. Lapena, L. Lomba, M. Artal, C. Lafuente, B. Giner, Fluid Phase Equilib., 492, 1 (2019).

Vida Vičkačkaitè, Agnieška Jevtuch, Vilius Poškus, Birutė Bugelytė

\section{TIRPIKLIŲ LIKUČIŲ FARMACINIUOSE PREPARATUOSE NUSTATYMAS VIRŠERDVĖS DUJŲ CHROMATOGRAFIJOS METODU: DVIEJŲ MATRICOS TERPIŲ PALYGINIMAS}

Santrauka

Dimetilformamidas (DMF) ir eutektinis tirpiklis cholino chloridas-etilenglikolis (ChCl-Eg) buvo ištirti kaip potencialios matricos terpès atliekant statinị viršerdvès dujų chromatografinị (SHS-GC) tirpiklių likučiu nustatymą farmaciniuose preparatuose. Buvo optimizuota méginio termostatavimo temperatūra ir trukmè bei ileidimo trukmè. Naudojant DMF méginys buvo termostatuojamas $140{ }^{\circ} \mathrm{C}$ temperatūroje, o ChCl-Eg termostatavimo temperatūra negalejo viršyti $80{ }^{\circ} \mathrm{C}$, nes aukštesnèse temperatūrose ChCl-Eg èmè skilti. Aukštesnè termostatavimo temperatūra naudojant DMF sudarè palankesnes sąlygas analitėms pereiti $\mathfrak{x}$ viršerdvę ir nulèmè mažesnes analičiu aptikimo ribas. Nuspręsta, kad dimetilformamidas yra tinkamesnè matricos terpé nei ChCl-Eg. DMF buvo naudojamas tirpiklių likučiams nustatyti vaistuose SHS-GC metodu. 